\title{
Study of the thermally sprayed Zn coatings in the context of use in special purpose articles
}

Keywords:

flame spraying;

Zn coating;

study of thermally sprayed coatings

\begin{abstract}
The paper presents the results of operational tests of thermal sprayed zinc coatings of various thicknesses on non-alloy steel substrates. The resistance of coatings to: variable temperature cycles, increased ambient humidity, salt fog as well as the electrical resistance of the coating and its adhesion to the steel substrate were tested. It has been shown that $\mathrm{Zn}$ coatings has a high corrosion resistance in various atmospheric conditions and have satisfactory properties so they can be protective layers of machine parts used in the armaments industry.
\end{abstract}

\section{Introduction}

Products for special purpose, e.g. military vehicles must meet specific requirements, much more restrictive than civilian vehicles. Tanks, rocket launchers, radars, as well as transport vehicles must meet the high endurance requirements to which they may be exposed during exploitation and military operations, while ensuring the safety of people inside and at the same time be fully reliable. The strength requirements are: static, dynamic and fatigue loads that affect a given product, but also atmospheric factors. The military vehicle must be able to work in a hot and dry desert, during very low temperatures as well as on a salty and humid wharf. In addition, military vehicles due to their features, such as high mechanical strength, specialized equipment, or modern software become very expensive, that is why a long service durability is required from them. It is obtained by selecting the elements with the highest reliability coefficient. There is also the issue of long-term resistance to atmospheric factors. This task is not easy to accomplish. A difficult condition to meet is to provide resistance to the salt fog that occurs over the seas and oceans. The salty fog occurring over salt water reservoirs is one of the most aggressive atmospheric factors that a vehicle can encounter. In order to protect the interior of the vehicle from the action of salt mist, dust and other environmental factors, various types of seals are used. However, external elements that are directly exposed to these factors are made of materials resistant to corrosion or protected by protective coatings. These coatings must also be resistant to atmospheric conditions and meet the requirements of electromagnetic compatibility, i.e. they must not interfere with the operation of other devices and must be resistant to external interference. For a protective coating, this means providing a constant electrical potential over the entire surface, and therefore a low coating resistance.

The aim of the work was to test resistance to atmospheric factors and selected functional properties of flamesprayed zinc coatings in the context of their use in products for military use.

\section{Materials and devices used}

On the basis of literature analysis $[1 \div 3]$ and previous research of various coating materials [4], a material with the trade name of RotoTec LT 29230 from Messer Eutectic Castolin was selected. According to the manufacturer's data, this material is in the form of a spherical powder, with a granularity in the range of $36 \div 106 \mu \mathrm{m}$ and contains $99.8 \%$ of zinc [5]. It is used for the production of coatings with high corrosion resistance.

S355J2 steel was used as the base material. The chemical composition of this steel is shown in Table I. For the tests,

dr inż. Mariusz Bober - Warsaw University of Technology;

mgr inż. Rafał Milczarek, mgr inż. Marek Żubrowski - PIT-RADWAR;

mgr inż. Wojciech Sokołowski - Messer Eutectic Castolin

Corresponding author. mbober@wip.pw.edu.pl 
Table I. The chemical composition of S355J2 steel according EN 100025-2:2007 [6]

\begin{tabular}{|c|c|c|c|c|c|c|c|c|c|}
\hline Element & $\mathrm{C}$ & $\mathrm{Mn}$ & $\mathrm{Si}$ & $\mathrm{P}$ & $\mathrm{S}$ & $\mathrm{Cr}$ & $\mathrm{Ni}$ & $\mathrm{Al}$ & $\mathrm{Cu}$ \\
\hline Content [\%] & 0.2 & 1.5 & $0.2 \div 0.5$ & $\max 0.04$ & $\max 0.04$ & $\max 0.3$ & $\max 0.3$ & $\max 0.02$ & $\max 0.03$ \\
\hline
\end{tabular}

samples with dimensions of $50 \times 450 \mathrm{~mm}$ and $150 \times 110 \mathrm{~mm}$ were cut out from a $6 \mathrm{~mm}$ thick sheet metal. Prior to spraying, the surface of the substrates was subjected to abrasive blasting using glass abrasive material. After machining, the steel substrates were cleaned with compressed air, and just before being sprayed, heated to a temperature of about $80^{\circ} \mathrm{C}$ to remove moisture [3].

In products as precise as military equipment, deformations of the material resulting from the interaction of the heat source in the spraying process are unacceptable. In contrast, the thickness of the modified elements is in a wide range - from thin to very thick. In connection with the above, a powder flame spraying was used to apply the coatings. In addition, due to the low temperature of the process, there are also no structural changes and the base material retains its mechanical properties.

The spraying process was carried out using CastoDyn DS 8000 torch from Messer Eutectic Castolin. The working gas used for the spraying process was acetylene and subsidiary, to give the proper energy to the molten particles was compressed air. The following process parameters are used: acetylene pressure 0.7 bar, oxygen pressure 4 bar, air pressure 3 bar and the distance of the nozzle from the welded surface was $250 \mathrm{~mm}$.

Coatings of zinc powder were applied to suitably prepared steel substrates with a thickness of: $0.5,0.75$ and $1 \mathrm{~mm}$. In addition, a special RotoGuard substance from Messer Eutectic Castolin dedicated to the sealing of sprayed coatings was applied to the half of the surface of each coating.

\section{Examinations of the coatings}

\section{Macro and microscopic examinations}

Figure 1 shows the view of coatings after the spraying process. The darker side of the coatings is additionally covered with a sealing RotoGuard substance.

Figure 2 shows the microstructure of the zinc coating on a non-alloy steel substrate. The continuous boundary between the coating and the steel substrate free from welding incompatibilities is visible. The coating has a layered structure characteristic of thermal spraying processes. Also few particles of Zn powder and porosity are visible.

\section{Climatic research}

For the sprayed samples a series of climatic tests was carried out based on the defensive standard NO-06-A107:2005 [6]. These tests were aimed at simulating the conditions that a product with a military destiny might come across. Simulations concerned both the impact of temperature changes and atmospheric conditions, i.e. increased humidity and salt fog.

\section{Cycles of variable temperature}

The study of the influence of temperature changes was carried out in the climate chamber ACS UY 1200 VT. The temperature range that the chamber can generate is from $-30{ }^{\circ} \mathrm{C}$ to $+100{ }^{\circ} \mathrm{C}$, and the range of air humidity from 10 to $95 \%$. The samples were placed in a climate chamber and subjected to three cycles of temperature change in the range from $-30{ }^{\circ} \mathrm{C}$ to $+65^{\circ} \mathrm{C}$. The temperature changes took place at a heating
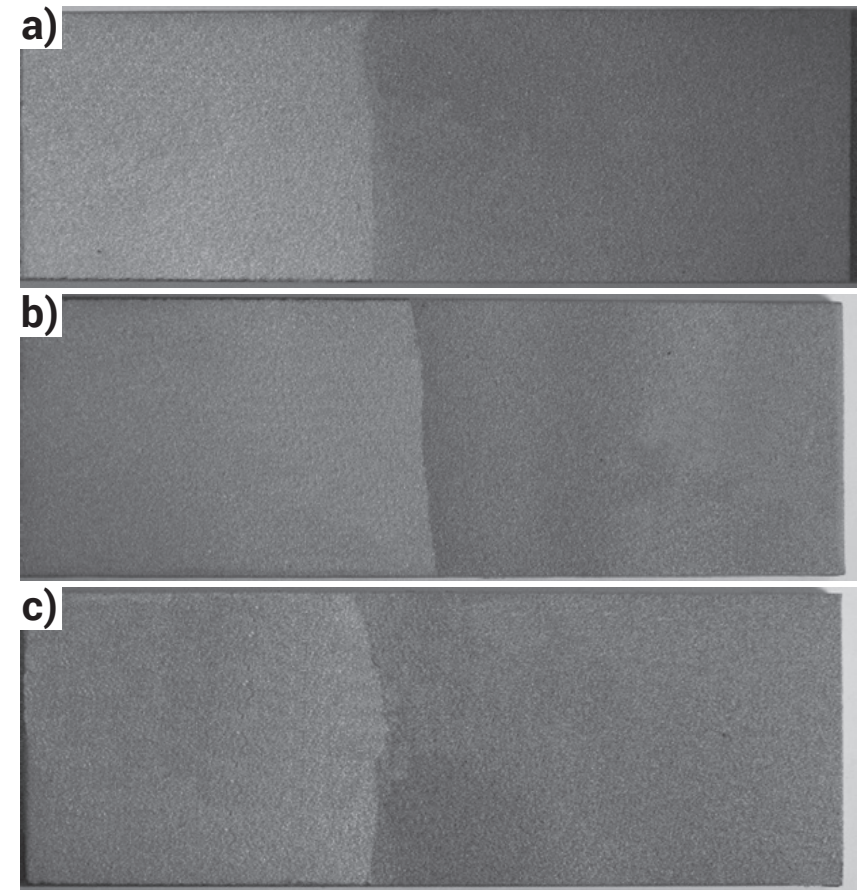

Fig. 1. View of samples after the spraying process with different coating thickness: a) $0.5 \mathrm{~mm}$, b) $0.75 \mathrm{~mm}, \mathrm{c}) 1 \mathrm{~mm}$. Darker side (right) coated with RotoGuard

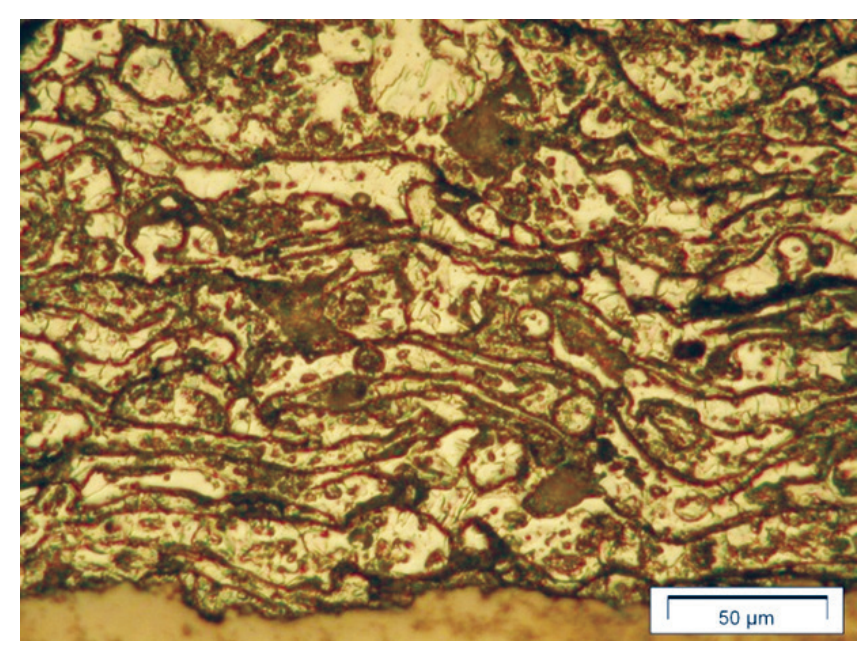

Fig. 2. The microstructure of the zinc coating

rate of approx. $2{ }^{\circ} \mathrm{C} / \mathrm{min}$ and cooling of approx. $1{ }^{\circ} \mathrm{C} / \mathrm{min}$. In addition, each time after reaching the extreme temperature, they were kept in it for 3 hours. After the temperature cycles were completed, the samples were visually inspected (Fig. 3). These studies were carried out with an unaided eye. Based on these observations, no changes in coatings or corrosion focals were found.

\section{Cycles of increased humidity}

In the same climatic chamber samples were exposed to increased ambient humidity. For these loads, the samples were subjected to a more complex process, which consisted of:

- Ten 24-hour cycles in relative humidity of approx. 95\%, each cycle containing: 


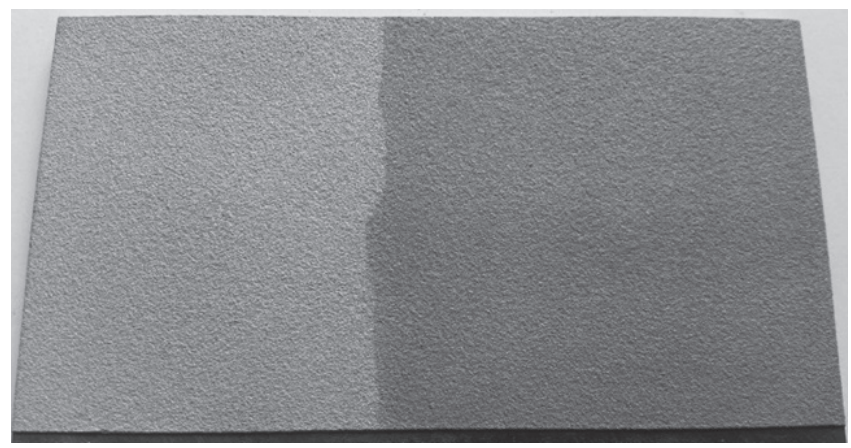

Fig. 3. Appearance of the sample with a coating thickness of $1 \mathrm{~mm}$ after testing at cyclically varying temperature

- slow heating of the chamber to the temperature of $40 \pm 2{ }^{\circ} \mathrm{C}$ and maintaining this temperature for a period of 12 hours counted from the beginning of the cycle;

- gradual cooling of the chamber to a temperature of $25 \pm 2{ }^{\circ} \mathrm{C}$ and maintaining this value until the end of the cycle;

- 120 hours without a break at $93 \pm 3 \%$ humidity and at a temperature of $40 \pm 2{ }^{\circ} \mathrm{C}$.

After the tests, a visual assessment was made and minor corrosion focals were observed on the steel substrate (Fig. 4). On the other hand, coatings did not show corrosion focals on any of the samples.

\section{Examination of the influence of salt fog}

The last climate test was to check the total resistance to the effects of salt mist. This test was carried out in the corrosion test chamber according to ISO 9227:2017 [8]. The chamber simulated the conditions that are found on the salt sea, such as high humidity and salinity.

The corrosion test was also carried out according to the NO-06-A107-2005 standard parameters:

- Duration of the test: $168 \mathrm{~h}=168$ cycles;

- Corrosive cycle, 1 hour: 15 minutes of spraying brine + +45 minutes of holding;

- Brine concentration: 3\% (30 g NaCl per liter of demineralised water);

- Brine density: $\rho=1,017 \mathrm{~g} / \mathrm{cm}^{2}$;

- Exposure temperature: $35{ }^{\circ} \mathrm{C}$ (during spraying and holding without spraying).

After the salt fog resistance test, the samples were rinsed in lukewarm water and dried. The appearance of the sample after the corrosion test is shown in Figure 5. A white coating of salts on the coatings is visible, but no corrosive focals were observed. In turn, the base material (S355J2 steel) has been significantly damaged in corrosion. In the paper [9] similar results of resistance of zinc coatings to aggressive atmospheric agents were obtained.
Climate tests have demonstrated the high resistance of zinc coatings to various atmospheric factors. However, the effect of sealing the coating with RotoGuard substance against corrosion resistance was not observed.

\section{Measurement of adhesion of coatings to the substrate}

The adhesion measurement of sprayed coatings was determined using the peeling method based on the PN-EN 582:1996 standard [10]. In this method the adhesion of the coating is determined as the result of the quotient of the maximum force used in the sample and the cross-sectional area of force. The standard recommends the execution of min. 3 attempts, and the increase in force should not be greater than $1000 \mathrm{~N} / \mathrm{s}$. To make the measurements of the adhesion of coatings, punches with a diameter of $20 \mathrm{~mm}$ were used. Before the experiment, the surfaces of the punches were properly prepared by abrasive blasting, and then degreased together with the samples of the coatings. Based on preliminary tests [4], a two-component Soudal adhesive - Epoxy Extra Strong was selected. The punches were glued at equal intervals of 3 pieces on each of the samples. Adhesion measurement was made using the Elcometer 510T device. The test results (Fig. 6) show that the adhesion of the zinc sprayed layers to the substrate decreases as the coating thickness increases. This may result from an increase in the state of stress resulting from different properties of the coating and substrate materials $[2,11]$. The literature data show that the adhesion of zinc coatings applied with the arc method is on a similar level [2], as well as ceramic coatings also sprayed with CastoDyn DS 8000 burner [12]. In contrast, the use of a sealing substance has significantly improved the adhesion of the coatings to the substrate. In all of the tests carried out, destruction of the joint along the coating-steel interface was observed (Fig. 7).

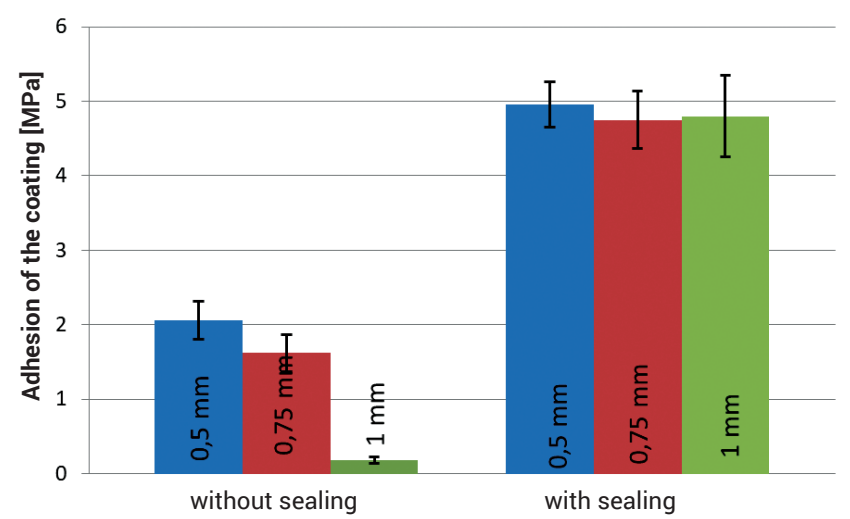

Fig. 6. The results of measurement of the adhesion of the sprayed zinc coating to the steel substrate

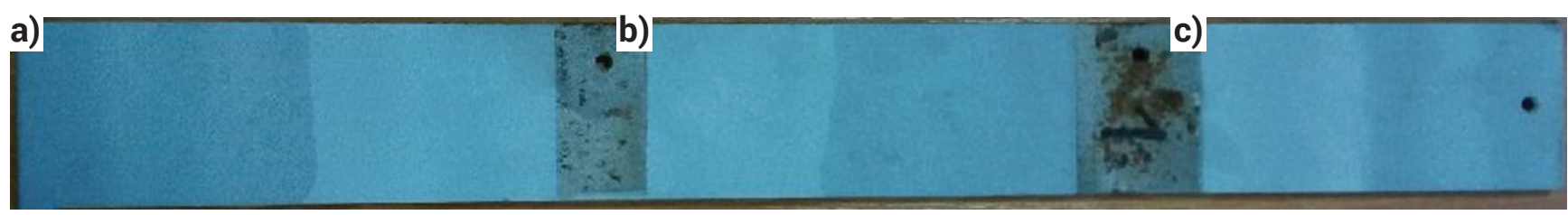

Fig. 4. The appearance of the samples with a thickness of $0.5 \mathrm{~mm}(\mathrm{a}), 0.75 \mathrm{~mm}$ (b) and $1 \mathrm{~mm}$ (c) after testing at elevated humidity

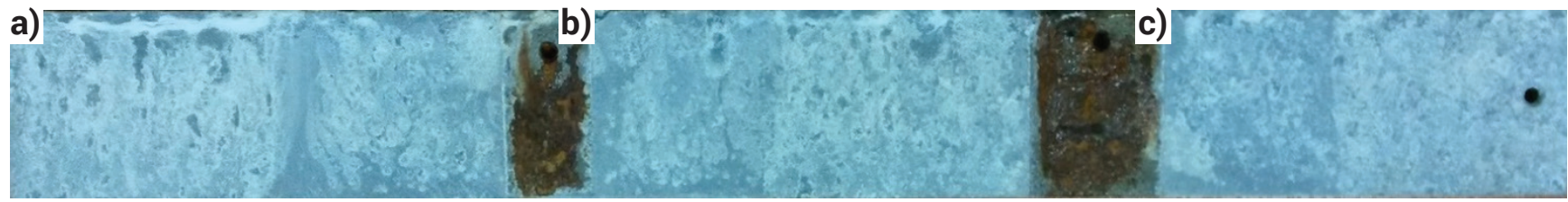

Fig. 5. The appearance of sprayed coatings with a thickness of $0.5 \mathrm{~mm}$ (a), $0.75 \mathrm{~mm}$ (b) and $1 \mathrm{~mm}$ (c) after the test of resistance to salt spray 


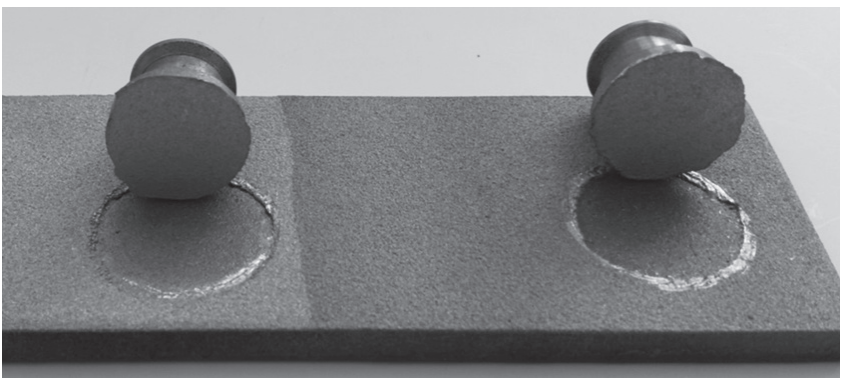

Fig. 7. Adhesive nature of the destruction of the connection between the substrate and the coating

\section{Research on electrical resistance of coatings}

The transition resistance is a parameter that indicates the resistance of the current flow through the contact point of the two conductive elements. The transition resistance depends on several factors:

- own resistance of both elements;

- the shape of the contact area;

- layers that are found on the contact surfaces.

In the sprayed coatings, the resistance of transition between the coating and the substrate was tested. This is important for ensuring electromagnetic compatibility and massification of the elements on special vehicles. Thus, it is desirable to obtain the lowest possible transition resistance value, which will indicate good conductivity of the coating and its tight adhesion to the substrate. This parameter was measured using a Sonel meter, model MMR-600. It is characterized by a resistance measurement range from $1 \mu \Omega$ to $200 \Omega$, for a current intensity from $0.1 \mathrm{~mA}$ to $10 \mathrm{~A}$, with a measurement error of $\pm 0.25 \%$. The measurement was made at a distance of 50 and $100 \mathrm{~mm}$ from the point of application of the test voltage. The tests showed that the application of the sealing substance did not significantly affect the resistance of the layers (Fig. 8). The differences in coating resistances are insignificant. In contrast, Figure 9 shows the result of resistance measurements of coatings of different thickness before and after climate tests. The measurement distance

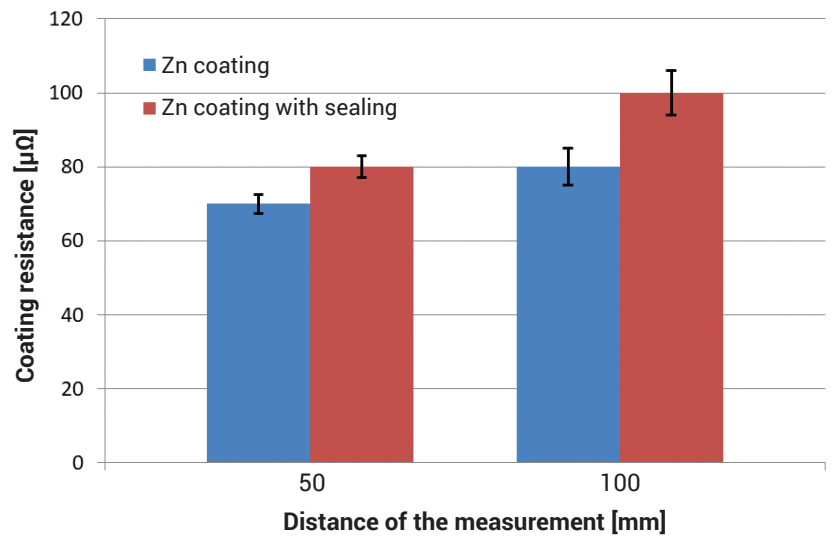

Fig. 8. Resistance of $\mathrm{Zn}$ sprayed coatings with and without sealing agent

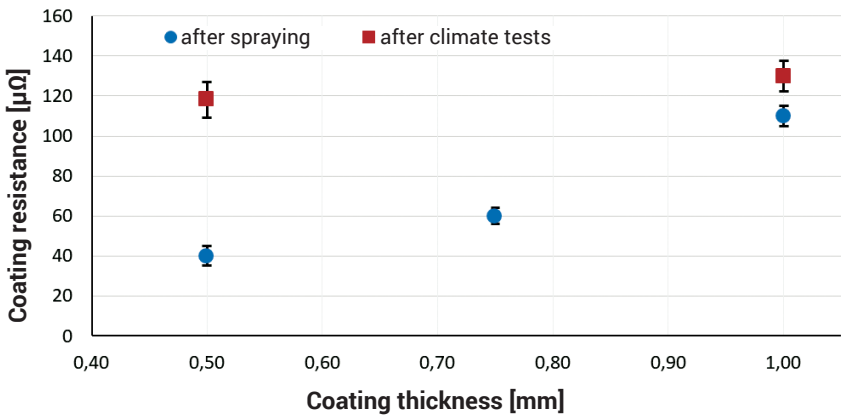

Fig. 9. The results of electrical resistance measurements of coatings

was $50 \mathrm{~mm}$. The data shows that as the coating thickness increases, the resistance increases. Increased resistance of coatings after climate tests was also demonstrated. This effect resulted not from the degradation of the coating but from the fact that the coating was covered with a thin layer of salt. This layer insulated the current flow sufficiently, that in some cases the resistance measurement was impossible or subjected to a large error.

\section{Conclusions}

The following conclusions can be drawn on the basis of the conducted research:

- The tests carried out confirm that zinc coatings show very high resistance to corrosion in variable temperature, high humidity and salt fog conditions. The application of RotoGuard sealing substance does not affect the corrosion resistance of the coatings.

- There is a tendency to reduce the adhesion of zinc coatings to the substrate as their thickness increases. A significant increase in adhesion was obtained by applying a RotoGuard sealing substance to the coating.

- The electrical resistance of the sprayed coatings is relatively low and increases with increasing thickness of the layers.

- Coatings after climatic tests show greater electrical resistance due to the presence of a thin $\mathrm{NaCl}$ film covering the sprayed layer.

- The use of RotoGuard sealing substance has no significant effect on increasing the electrical resistance of coatings. 


\section{References}

[1] M.H. Mathabatha, A.P.I. Popoola, O.P. Oladijo, Residual stresses and corrosion performance of plasma sprayed zinc-based alloy coating on mild steel substrate, Surface and Coatings Technology (2017), vol. 318 293-298.

[2] T. Chmielewski, D. Golański, J. Bazela, G. Gontarz, Badania właściwości powłok Zn i Al natryskiwanych łukowo na stal S235JR, Welding Technology Review (2014), vol. 86(2), 7-13.

[3] A. Klimpel, Technologie napawania i natryskiwania cieplnego, Wydawnictwo Politechniki Śląskiej, Gliwice (1999).

[4] R. Milczarek, Badania powłok natryskiwanych cieplnie w kontekście zastosowania do wyrobów o przeznaczeniu specjalnym, Praca Dyplomowa, ZIS PW, Warszawa (2016).

[5] Materiały firmy Castolin Eutectic: https://www.castolin.com/pl-PL/.

[6] PN-EN 10025-2:2007 Wyroby walcowane na gorąco ze stali konstrukcyjnych - Część 2: Warunki techniczne dostawy stali konstrukcyjnych niestopowych.
[7] NO-06-A107:2005 Uzbrojenie i sprzęt wojskowy - Ogólne wymagania techniczne, metody kontroli i badań - Metody badań odporności całkowitej na działanie czynników środowiskowych.

[8] PN-EN ISO 9227:2017-06 Badania korozyjne w sztucznych atmosferach - Badania w rozpylonej solance.

[9] H. Katayama, S. Kuroda, Long-term atmospheric corrosion properties of thermally sprayed $\mathrm{Zn}, \mathrm{Al}$ and $\mathrm{Zn}-\mathrm{Al}$ coatings exposed in a coastal area, Corrosion Science (2013), 76, 35-41.

[10] PN-EN 582:1996 Natryskiwanie cieplne - Określanie przyczepności metodą odrywania.

[11] T. Chmielewski, D. Golański, G. Gontarz, Pomiar naprężeń własnych powłok metalicznych natryskiwanych termicznie, Welding Technology Review (2011), vol. 83(12), 59-64.

[12] A. Czupryński, A. Ozogowicz, Analiza właściwości powłokowych barier cieplnych natryskiwanych płomieniowo, Welding Technology Review (2014), vol. 86(12), 9-19.

(C) 2019 by the authors. Submitted for possible open access publication under the terms and conditions of the Creative Commons Attribution (CC BY) license (http://creativecommons.org/licenses/by/4.0/). 